\title{
Principles and Pilfering: Nottingham Lace Design Pedagogy
}

\section{Abstract}

This paper explores the lace design pedagogy that developed in Nottingham during the first half of the twentieth century. It draws on teaching material and student work collected in the Nottingham Trent University Lace Archive and examines three sets of material in particular: portfolios of student drawing; a collection of lace draughts composed for teaching purposes; and student designed lace samples. These materials are records of a learning process influenced both by a national education system and the local lace industry. While the former were concerned to reproduce a canon of ornamentation obeying certain design principles, the later needed designers possessing specific technical skills and the ability to copy and adapt existing designs suitable for mass production and consumption. Lace design pedagogy encompassed the 'principles' of design, the 'technique' of design and the 'business' of design. In each of these fields, students learnt by copying, so that copying was, to some extent, both the method and the outcome of Nottingham lace design education.

Lace, Nottingham, History, Design, Education, Pedagogy 


\section{Principles and Pilfering: Nottingham Lace Design Pedagogy}

\section{Introduction}

The ways in which designers in the UK were educated, before the growth of Bauhaus inspired formal practices in the 1950s, is regrettably under researched (Souleles, 2013; Schmeichen, 1990). Some scholarship, however, has followed the careers of educators and investigated the development of formal design education (i.e. Daichendt, 2011; Quinn, 2011; Romans, 2005; Haslam, 1988; Swift, 1988; Macdonald, 1970; Bell, 1963) and here we continue this work. This paper explores the design pedagogy that developed in Nottingham's School of Design and in relation to Nottingham's lace industry in the first half of the twentieth century. This pedagogy was influenced by an education structure concerned to teach the principles of design and by an industry concerned with technical skill and the development of design suitable for mass production and consumption. It taught the principles, technique and business of design.

In order to excavate this historical design pedagogy, the paper draws on research conducted primarily in the Nottingham Trent University Lace Archive. The archive was initially established when lace manufacturer, scholar and campaigner William Felkin (1796-1874) donated a set of pattern books to the Nottingham School of Design for teaching purposes. It was augmented as a teaching resource by acquisitions and donations of books, pattern books, lace, lace designs and lace draughts into the 1950's (Briggs-Goode, 2013). The archive also contains the work of lace design students produced at least as early as 1917 and at least as late as 1961 . This paper explores how this material informs our understanding of how lace design was taught and learnt during this period.

\section{Nottingham Lace Design}

Machine made lace, particularly 'Nottingham lace', was rooted in practices of imitation from its beginnings. The original objective of machine made laces was to make a fabric that looked and felt like hand made bobbin lace but to make it much more quickly and cheaply. It was first made during the early nineteenth century as machines were developed in Nottingham which could imitate the technique of twisting threads particular to hand made bobbin lace. Its designs were often variations on already existing lace styles and motifs. Nottingham was not without its talented designers who, while working in the machine made lace trade, also produced award winning design work in other fields (i.e. Ferry, 2014). Nor was it without innovative machine made lace design. Yet most lace produced conformed to longstanding styles.

The lace design process involved first developing a 'sketch', then a full 'design'. The design was then converted into a 'draught' ${ }_{L}$ plotting in coloured ink the journey of the different threads which were to compose the lace. Lastly, the draught was translated into numbers on a 'sheet', from which Jacquard cards, used to programme the lace machine, could be punched. Lace makers, scattered throughout the East Midlands, owned or rented the machines that made lace while manufacturers, usually based in Nottingham's Lace Market, finished and marketed it. Specialist design firms existed but large makers would have an in-house design team, and freelance designers were also at work. The Nottingham School of Art Alphabetical Lists of Students (held at the Nottingham City Archives) show that females were training as lace designers from at least as early as 1901 but there is little evidence of them working in the major lace houses. Amy Atkins 
trained at the School and claimed to be the first professional female lace designer. She appears to have worked on a freelance basis, selling to numerous lace houses, but ceased work on marriage in 1914. In very large factories, the role of 'designer', 'draughtsman' and 'reader-off' (sheet maker) were distinguished. Many employees worked in each role, specialising in a particular type of lace. They were supported by young 'copiers' or 'improvers' to fill-in or duplicate the more repetitive areas of designs and draughts. Designers, however, would necessarily know how to draught in order to design and in small lacemaking firms the proprietor was sometimes his own designer and draughtsman. Designers with a particular role at work might also undertake the whole designing and draughting process freelance in their spare time (Varley, 1959; Pollard, 2006).

Despite its generally conservative nature, the process of producing a lace design was complex and expensive and details of designs were fiercely guarded secrets. In 1838 the authorities in Calais established the registres du dépôt légal (legal deposit registers) of the Conseil Des Prud'hommes in order to combat the increasing number of legal disputes relating to the ownership of lace designs (Baxter, 2015). A year later Nottingham lace designs could be registered for copyright with the English Board of Trade. The Board of Trade Design Registers were formed of two complimentary parts; a sample of the lace (or drawn design) to be copyrighted would be given a registration number and deposited in a Volume of Representation and the name and address of the person or company claiming the copyright would be held in a corresponding Register (Eastop, 2011-12). Lace Manufacturers would add a label with the registration number to the samples in their records and sample books. The Board of Trade Design Registers, now held at The National Archives (Kew), contain a wide range of materials, within the series BT43 and BT44, covering the years 1842-1883/4, lace formed Class 13 (Eastop, 2011-12). That lace had its own Class is an indication of the number of designs that were being registered. There remained however, "inseparable difficulties in the way of proving either originality or piracy of patterns" (Felkin, 1867). Eventually a registration office dedicated to the industry was opened in Nottingham, yet disputes continued to occur. In 2018 international lace manufacturers Tianhai won a court battle with clothing retailer Reiss who admitted infringing the copyright of one of Tianhai's floral lace patterns. A spokesperson for Tianhai said: "We will take every effort and action to protect our copyright. We hope the textiles and garment industries can realize the importance of using original designs - doing so creates a better environment for suppliers and manufacturers alike" (Fisher, 2018).

Lace design was originally learnt during apprenticeships, which were sometimes supplemented by evening classes at the Mechanics Institute and eventually at the Nottingham School of Design, which opened in 1843. The Government Schools of Design, of which the Nottingham school was one, were founded to assist manufacturing towns to compete in international markets. Their establishment responded to the perception that the UK lagged behind other European states in producing original high quality design (McDonald, 1970). Operating alongside provincial museums, the schools were also intended to improve the nation's taste and spread knowledge of the principles of design (Romans, 2004). It was hoped that an industrial culture would develop in which consumers would purchase objects obeying the principles that objects that were "desirable" because they were "admirable" (Jones, 1993). It was hoped that design would safeguard economic success, public morality and political stability; that it would be "a language of abstract ideals" to link "the skill of labour and the power of capital within an all 
embracing unity and proper order" (Rifkin, 1988). The schools established teachable principles of ornamentation specifically for the industrial arts (Cardoso, 2004; Bell, 1963).

The Nottingham lace industry was oriented to producing large quantities of cheap and fashionable goods for the mass market. It was said that the Nottingham lace industry catered for "the masses and not the classes" (Brompton, 1997). A parallel lace industry had grown in France, after machines were smuggled across the channel to Calais in 1816, which catered for the market in luxury lace (Mason, 1994). The Nottingham industry had undergone huge expansion and by the turn of the twentieth century was exporting internationally on a vast scale. It was technologically rather than design led: investment which might have gone into lace design, tended to pay for the purchase and upgrading of machinery (Smith, 1995). To be commercially viable in this market, a pattern would have to be simple and 'short', and work in wide and narrow versions (Nottingham Daily Express, 29/01/1917). Lace was often sold in sets of different widths and it was an essential part of a designer's role to adapt an initial design motif for a series of laces including various widths of insertions and edgings and possibly allover fabrics as well.

A lace would also need to be salable in large quantities over many years (Felkin, 1867). Nottingham's Lace Market, with its high-class showrooms and mass of female workers, was a place where the interpretation and anticipation of fashion dominated (Nix, 1997). Rather than entrusting design to a designer, manufacturers would often select an existing lace they expected to sell well and have it adapted (Nix, 1997). While manufacturers had to be aware of changing fashion and be open to novelty, they were aware that more extreme designs tended not to sell well.

The competitive nature of the Nottingham industry discouraged lace makers and manufacturers from supporting the training of designers who might then "go somewhere else for more money" (Nottingham Daily Express, 20/1/1917) or who might share with fellow students their firm's guarded lace designs and draughts (Smith, 1995; Mason, 1994). Nevertheless, a lace designer was essential to the process of taking an idea for a lace to the stage where it could be manufactured. The first president of Nottingham School of Design was the lace manufacturer Richard Birkin and a segment of manufacturers continued to support the School and its day and evening courses for lace designers (Jones, 1993). Other manufacturers remained skeptical. The School of Design had to follow the national government curriculum, which was centered around the copying of classical designs, and it was criticised for being a "mere drawing academy" (Jones, 1993). It was said that a mutual misunderstanding developed in which it was thought by the industry that the school "did not care about the lace trade" and by the school that "all the lace trade wanted was somehow cheap and nasty" (Nottingham Daily Express, 20/1/1917). The dilemma for Nottingham, as for all the Schools of Design, was whether to emphasize general art education or specialist skill training (Schmeichen, 1990).

In 1913, the national syllabus for the schools was relaxed, making it easier for them to respond to the needs of their local industries (Nottingham Daily Express, 7/10/1913). Lace machines were introduced to the school to give the training of designers "a more technical character" (Nottingham Daily Express, 29/1/1917). Its teaching came to encompass the three key elements of; the principles of design, the techniques of lace draughting and the business of making conventional types of lace. The Federation of Lace and Embroidery Employers Associations praised how teaching in the school combined instruction in the drawing of historic lace and floral form with draughting and the design of lace which met industry standards (TFLEEA, 1924). Indeed 
by the 1930's, the Nottingham School of Design, now Nottingham College of Arts and Crafts, was defending its industry-specific focus. "Whilst I own that those who sit in judgement on our works are men of the highest calibre", the then Principal, who had spent his youth as an assistant in a lace designer's office, argued, "I doubt that any but ourselves can truly assess the appropriateness of [the students'] efforts to the needs of our staple trades" (Jones, 1993). Over decades of interplay between education and industry structures, a distinctive lace design pedagogy had emerged. This dialectical/iterative process between educators, designers and those who marketed the lace had also been of great influence on the technological advances in the equipment that made the product.

By this time, however, the industry was already beginning to decline. It had been suffering from a perception among consumers that its design was sub-standard. Manufacturers complained that "debased design and slack quality" had made "Nottingham lace stink amongst the better class buyers of the world"; they had been caught in a "mad downward policy" which made Nottingham lace now in need of "rehabilitation" (Nottingham Daily Express, 20/1/1917). By the 1940s the skilled labour the industry required was in short supply and the lack of demand for new design during the war and then in buoyant post-war markets - in which all lace could be easily sold - did nothing to increase it (Varley, 1959; pp.167-171). A number of attempts were made to rejuvenate lace design education and lace design was taught, at what became Trent Polytechnic, into the 1980s. However, changing taste and increasing international competition meant that the decline in the Nottingham based lace industry was never reversed.

\section{The principles of lace design}

Students never got any satisfaction out of copying. And I don't for that matter. [...] If someone walked through this door now and said "Can you do a design for me?" [...] I've got my pencil in my pocket and I could do one. - Brian Smith_(2016)

From at least as early as 1911, most lace designs students at Nottingham School of Design studied for four years, often part-time, while also in work. They learnt to copy 'from the antique' and to draw 'from memory'. They also studied the origination of design intended for industrial production: "the invention of a design on a given motif for a specified purpose, which must be practically adapted to production" (Chambers, 1911). This syllabus, which focused on the drawing of a cannon on ornament, plant form and historic laces, remained part of the course until the postwar period (City of Nottingham College of Art And Crafts Prospectuses, 1935-49).

The Nottingham Trent University lace archive contains two substantial collections of student drawings: a portfolio of examination work and a portfolio of drawings and designs belonging to a single student. The portfolio of work for examination contains repeated cycles of exercises, performed by a series of students, on which names have been erased. The work is not dated, although '1917' can be discerned on one piece of work and one name is, unintentionally, discernable - that of Lawrence Jarvis. According to the registers of Art School students held in the Nottinghamshire Archives, Jarvis had arrived at the school in 1915 at the age of 14 . The student 
portfolio belonged to Charles Lawson. According to birth records, Lawson was born in 1894 to a mother who worked as a lace mender and, according to 1911 Census data, by the age of 17 he was working as a lace draughtsman. The register of students indicates that he began his studies in 1907, also at the age of 14. Lawson won local prizes for his lace embroidery designs in 1911 and 1916 and was still taking evening classes at the School in 1917.

Both portfolios include copied and 'from memory' drawings of floral forms and copies of ornamental motifs and patterns published in The Grammar of Ornament (Jones, 1856). This book contains a collection of examples of ornamental art with sections on 'Egyptian' 'Mediaeval' and 'Renaissance', 'Celtic', 'Roman', 'Hindoo' and 'Chinese' work. "Whenever any style of ornament commands universal admiration", the book's author writes, "it will always be found to be in accordance with the laws which regulate the distribution of form in nature. [...H] owever varied the manifestations in accordance with these laws, the leading ideas on which they are based are very few" (Jones, 1856). Lawson's portfolio also contains many detailed drawings of historic hand made laces, accompanied by labels naming their styles. It also contained a number of fine designs for lace in Chinese White on tracing paper.

The examination exercises include developments of copied drawings, which take elements of them and adapt them into lace motifs and, in some cases, into complete lace designs. Some designs take inspiration from multiple sources. One sheet, in Chinese White on black paper, features both an Egyptian motif copied from The Grammar of Ornament and a tulip copied from an encyclopedia (reproduced in Buchard, 2011). It combines developments of both these copies in a motif suitable for lace. Another sheet, pencil on white paper, features a drawing of 'Flemish Guipure' hand made lace alongside a drawing of a bearded iris, and combines elements from them to create a new lace motif. The students were learning to apply a cannon of approved design styles to the design of Nottingham lace. The process of copying from volumes such as The Grammar of Ornament taught the students about line, form, light and shade, proportion, balance and the importance of space in compositions. Drawing examples of historic hand made lace familiarised them with the styles of lace that they would be expected to know in their working life. Drawing plants, whether from life or copied from books, instilled an understanding of plant forms which, along with geometric motifs, would be a mainstay of their creative outputs. These lessons formed the building blocks from which the students constructed their own creative designs. The examination pieces needed to show clear correlations between the sources and finalised designs but Lawson's portfolio pieces also included much more advanced design work, more suitable for commercial production. The forms of copying undertaken by the students had an agenda of instilling a sense of 'good taste' and balance. This was quite different to the intention of the copying referred to by Brian Smith which was the copying of someone else's commercial lace design with just enough variation to escape copyright issues. Smith studied lace design in the 1950 s before going on to work as professional lace designer and later becoming a lecturer in lace design. Although this was beyond the period under consideration he was interviewed in order to gain insights into the realities of training and working in lace design, particularly those aspects which were generally left unrecorded as they were common knowledge at the time.

Fig 1. Copies of ornamentation and floral forms then developed into lace motifs. From the 1917 
portfolio of student work for examination.

\section{The technique of lace design}

That is the one thread that has that much twist on it that, when it's made, as soon as they draw the thread out that holds the lace together, it will naturally want to spring somewhere and that twist will manipulate those threads so they look as if they go out. And that was the clever bit. There were people who were renowned for doing just that. - Brain Smith (2016)

Smith was referring to designers and draughtsmen working in the 1950s, and onwards, but it is speculated that the same may well have applied historically. This sort of information, although well known within the industry at the time, is rarely recorded. Students learnt lace draughting as part of the technical skills they needed to become industry designers. The lace archive contains a teaching collection of lace draughts and samples which was put together in 1943 with material donated by 39 local lace makers and money donated by the lace manufacturer Price. It is a comprehensive collection of 172 professional lace draughts, some dating back to 1911, in which the whole spectrum of Leavers lace is represented, from narrow geometrics to wide floral and allover designs. The draughts were annotated with descriptions of "the merits or demerits of the laces together with warnings, particularly to students, of pitfalls to be avoided", by designer, draughtsman and teacher Walter Mycroft (Nottingham Guardian, 26/10/1943), a process which was continued by successive teachers until at least 1959.

The collection served as a reference for how to draught, which could be consulted as needed. Its instructions direct students to the best draughts to study in relation to a particular task and they highlight what in particular about the draughts should be imitated, for example: "Please study the shading that has been put in the gimping of the leaves and flowers. It is well done" (Mycroft, 1943b). Comments advise students to copy the draughts in order to gain an understanding of the techniques used: "When studying this front, I make the suggestion that you make a complete copy of it from the sheet. This will give you a good insight into the working of the band thread" (Mycroft, 1943c). Students were expected to absorb techniques for later application in their own designs: "Study this composition carefully for on this principle, it is possible to make a varied assortment of wide goods" (Mycroft, 1943d). They were also being asked to use their technical knowledge to think about design. Techniques that could be used as part of better designs are emphasised and creativity is encouraged:

This is a good type of a lightweight lace. The effect has not been explored to a very great length. With bourdon cord liners the effect would be good. Too, experiment with 'floss' gimps (as centre gimps) some good shading effects could be obtained. (Mycroft, 1943a)

Students were not only being prepared to reproduce the draughting techniques on display but to 
use their technical knowledge of draughting to improve lace designs. There is a great deal of skill involved in the practicalities of changing a lace design into a workable draught and, as Smith suggests, some people had a very good understanding of the creative translation required to move from design to technical practice.

Fig 2. Lace draught from folio 34 of the G. W. Price collection.

\section{The business of lace design}

A manufacturer would come in with a piece of fabric 'I've been to one of the big international textile fairs' and, with a pair of scissors, he had cut a bit of fabric off. 'Now can you do the same but different?'. So he would stand there and you would get your sketchbook out and you'd do something which looked similar [...Or] he'd come in with an idea. "This is good. I don't know why we stopped making it really. Can you do another one similar to that?". They don't mean copying but they mean the proportion of net to solid, the way it would have a sort of type of movement that would lead someone to recognise, that it would still have that same handwriting as the first one, but it was different. = Brian Smith (2016)

It is important to remember that lace design students were being prepared to work in a commercial industry; they needed to know not only the principles of good design but also how to apply these principles to products suited to a highly competitive marketplace. It was felt to be essential that students learnt to create designs which would be commercially viable rather than purely aesthetically pleasing. The students were learning not only the entire process of taking an original idea through to production but also the essential skills of adaptation that they would need in the workplace. The lace archive contains around 300 student-designed lace samples made between 1927 and 1961. These are collected in two books and often labelled with a name, date and pattern number - the earliest being 1927 and the latest 1957. There is also a box of draughts and sheets, on which the latest date is 1961, many of which can be matched to the student samples in the books. These draughts and sheets have mistakes, which have been marked and then corrected. They are then signed "Checked for punching" indicating that they could be sent off to the company who produced Jacquard cards so that they could then be made on the College's Leavers lace machines.

Many of the student samples are of types of lace being commonly produced around Nottingham. There are four lace samples by the student Ruby Potter, for example, and three of these are geometric Filet style edging pieces similar to many others made by students in the archive. Potter's first Filet piece is particularly similar to another made by student Joan Cox which it sits alongside and with which it shares common motifs. Students were engaged in exercises to produce specific styles of lace with specific elements. We can speculate that they were being asked to reproduce an existing commercial lace in a slightly adapted form.

Students were also learning to reproduce more unusual designs. G. Beesley, in 1954, made 
a bold eight-pointed star sample which appears to have been adapted from a design by the Witchcraft Design Company. A very similar design is included in a sample book of professionally produced 'fancy flounces' put together for the students in 1951. Beesley improved the design by adding a hole in the centre of the star and adding a more complex ground within the net area. Another contemporary and unusual sample - a lace depicting breaking waves - was made by student R. Newsum but we do not know whether the design was of his own conception or an adaptation like Beesley's.

The rest of Newsum's work is much more conventional and in it one can clearly see progression. The first two pieces consist of strips of net with different configurations of spots, holes, decorative grounds and rows of simple flower forms with different shapes, centers and liners. These nets, grounds and motifs are the basis for his later floral work which contains multiple decorative grounds and details such as veining in leaves, shading in petals and decorative middles to flowers. In looking at two similar Newsum pieces, one made in September 1946 and the other made in January 1947, it is possible to see how the second is an improvement on the first. The flowers and leaves, lost as grounds and shapes in the first, are fully visible as floral forms in the second. Newsum was developing his abilities as a designer able to produce the kind of lace design required by the industry.

Fig 3. Lace by student R. Newsum circa 1946.

\section{Discussion}

By the second decade of the twentieth century, educators has developed a Nottingham lace design pedagogy concerned with the abstract 'principles' of design, the 'technique' of designing for complex industrial processes and the 'business' of designing commodities for the mass market. This pedagogy was the meeting of a national education agenda to develop taste and the practices of the lace industry. It brought 'principles' together with 'pilfering'. Both agendas supported a pedagogy of copying and adapting which took three distinct forms. Students copied a particular cannon of ornamentation and floral forms and combined and adapted them into sketches for the design of Nottingham lace. Students also copied lace draughts so they could understand and practice the complex draughting process and adapt existing methods so as to improve the design status quo. In addition, the students copied, always in slightly adapted form, lace in contemporary production thereby learning to design variations on common and uncommon kinds of lace. The overarching aim of the students' education was to improve the design capabilities of the Nottingham lace industry but this was tempered by an understanding of the practicalities of responding to commercial design trends and customer requests.

From their very first days at the Art School the students' copying always had two dimensions. Firstly, it was a skill to be learnt. The Government Schools of Design had implemented a national syllabus of copying from a series of approved sources, such as Dyce's The Drawing-Book of the Government School of Design. Students were required to prove, at examination level, that they could copy these increasingly complex elements successfully. Secondly, it was a means of learning. Whether what was learnt were the eternal principles of proportion and balance or ever developing technical know-how, copying was a means of acquiring the knowledge and skill to go on to improve lace design. While the Government Schools of Design rewarded the reproduction of 
a cannon of design, the lace industry was seeking to employ designers who could produce refreshed versions of common laces as they came 'in' and 'out' of fashion. The industry also required them to be flexible enough to reproduce another company's design, retaining the style of the original, but with sufficient adaptations to make it appear to be a fresh new design.

More work is needed to fully understand Nottingham lace design pedagogy in its social, political and industrial context. Little academic research has been done into any aspect of Nottingham lace design and almost all existing scholarship about the industry in general has been produced by the industry itself. Much remains to be done in exploring the lives of Nottingham lace designers, the place of design within the industry and the nature of the design it produced. 


\section{Bibliography}

Baxter, G. (2015) Re-viewing Lace in Archives: Connecting the lacunae, PhD Thesis, University of Brighton

Bell, Q. (1963) The Schools of Design, London: Routledge \& Kegan Paul

Brompton, R. (1997) 'The growth in consumption and social decline of machine lace 18501900', ARS Textrina Vol. 28 pp.137-148

Briggs-Goode, A. (2013) 'Nottingham Trent University Lace Archive' In A. Briggs-Goode \& D. Dean (Eds.) Lace Here Now, Black Dog Publishing pp.41-52

Buchard, L. (ed.) (2011) Lace designs of Calais: 19th-21st centuries, Calais: Cité international de la dentelle et de la mode de Calais.

Chambers. E,K. (1911) Examinations in Art Certificates for Teachers of Art. Report in unknown Nottingham Newspaper, 30th December 1911. Nottingham

City of Nottingham College of Art And Crafts Prospectuses (1935; 1949). The Nottinghamshire Archives

Daichendt, J. (2011) 'The Nineteenth-Century Artist-Teacher: A Case Study of George Wallis and the Creation of a New Identity' International Journal of Art \& Design Education, Vol. 30, No. 1 pp. $71-80$

Dyce, W. (1842) The Drawing-Book of the Government School of Design, London: Chapman \& Hall Eastop, D. (2011-12) Exploring the potential of the Board of Trade Design Register. Text [Journal of (UK) Textile Society] Vol. 39 pp.52-6.

Felkin, W. (1867) A History of the Machine Wrought Hosiery and Lace Manufacturers, Longmans, Green and Company

Ferry, E. (2014) A Concomitant Orgy of Destruction: The political lace designs of W. H. Pegg, Conference Paper, Lace: The Transgressive Thread

Fisher, S. (2018) Lace manufacturer obtains judgement in copyright battle against fashion retailer. East Midlands Business Link. [online] At;

https://www.eastmidlandsbusinesslink.co.uk/mag/news/lace-manufacturer-obtains-judgementin-copyright-battle-against-fashion-retailer-reiss/ (Accessed on 05.12.2018)

Haslam, R. (1988) 'Looking, Drawing and Learning with John Ruskin at the Working Men's College' International Journal of Art \& Design Education, Vol. 7, No. 1 pp.65-79

Holdsworth, B. (1988) 'Marion Richardson (1892-1946)' International Journal of Art \& Design Education, Vol. 7, No. 2 pp.137-154

Jones, O. (1856) The Grammar of Ornament, London: Beenard Quaritch

Jones, C. (1993) A History of Nottingham School of Design, Nottingham: Faculty of Art \& Design Nottingham Trent University

Lowe, D. \& Richards, J. (1982) The City of Lace, Nottingham Lace Centre

Macdonald, S. (1970) The History and Philosophy of Art Education, London: University of London Press

Mason, S. (1994) Nottingham Lace 1760s-1950s, Stroud: Alan Sutton Publishing Ltd Mycroft, W. (1943a), G.W. Price Memorial Collection, Folio 122, Nottingham Trent University Lace Archive accession number NTOLA:1999:1492

Mycroft, W. (1943b), G.W. Price Memorial Collection, Folio 133, Nottingham Trent University Lace Archive accession number NTOLA:1999:1495 
Mycroft, W. (1943c), G.W. Price Memorial Collection, Folio 150, Nottingham Trent University Lace Archive accession number NTOLA:1999:1498

Mycroft, W. (1943d), G.W. Price Memorial Collection, Folio 213, Nottingham Trent University Lace Archive accession number NTOLA:1999:1489

Nenadic, S. (2014) 'Designers in the $19^{\text {th }}$ Century Scottish Fancy Textile Industry: Education, Employment and Exhibition' Journal of Design History, Vol. 27, No. 2 pp.115-131

Nix, J. (1997) Interpreting the Warehouse Landscape: Nottingham's Lace Market 1850 to 1920, PhD Thesis, Royal Holloway, University of London

Nottingham Daily Express, Arts Education in England, $7^{\text {th }}$ October 1913. Nottingham Nottingham Daily Express, New Life for the Lace Trade, $20^{\text {th }}$ January 1917. Nottingham Nottingham Daily Express, Lace School Wanted, $29^{\text {th }}$ January 1917. Nottingham Nottingham Guardian. Lace Secrets Pooled for Training Young Designers. 26 ${ }^{\text {th }}$ October 1943. Nottingham

Pollard, E. (2006) Pollards of Beeston: A century of lace making, Cranbrook: Ladoga

Quinn, M. (2011) 'The Political Economic Necessity of the Art School 1835-52' International Journal of Art \& Design Education, Vol. 30, No. 1 pp.62-70

Rifkin, A. (1988) 'Success Disavowed: the Schools of Design in Mid-Ninteenth-Century Britain' Journal of Design History, Vol. 1, No. 2 pp.89-109

Romans, M. (2004) 'Living in the Past: Some Revisionist Thoughts on the Historiography of Art and Design Education' International Journal of Art \& Design Education, Vol. 23, No. 3 pp.270-277

Romans, M. (Ed) (2005) Histories of Arts and Design Education Collected Essays, Bristol: Intellect Schmiechen, J. (1990) 'Design issues Reconsidering the Factory Art Labour and the Schools of Design in the Nineteeth-Century' Design Issues, Vol. 6, No. 2 pp.58-69

Smith, B. (1995) 'Dire Straights' Conference Paper: ARS Textrina, University of Nebraska, Lincoln, Nebraska (Unpublished)

Smith, B. (2016) Interview with Brian Smith - lace designer, ex-student at Nottingham College of Arts and Crafts and teacher at Nottingham Trent University. Conducted by the authors Friday $8^{\text {th }}$ April 2016

Souleles, N. (2013) 'The Evolution of Art and Design Pedagogies in England: Influences of the Past, Challenges for the Future' International Journal of Art \& Design Education, Vol. 32, No. 2. pp.243-255

Swift, J. (1988) 'Birmingham and its Art School: Changing Views 1800-1921' International Journal of Art \& Design Education, Vol. 7, No. 1 pp.5-29

The Federation of Lace and Embroidery Employers Associations (TFLEEA) (1924) Lace: The Fabric of Romance, Nottingham: TFLEEA

Thistlewood, D. (1993) 'Herbert Read: a Critical Appreciation at the Centenary of his Birth' International Journal of Art \& Design Education, Vol. 12, No.2 pp.143-160

Varley, D. E. (1959) A history of the Midland Counties Lace Manufacturers Association, Long Eaton: Lace Productions (1948) Ltd. 